\title{
Oil palm age and genotype interfere with defoliator lepidopteran infestation
}

\author{
Taciane Almeida de Oliveira' (10) https://orcid.org/0000-0002-0767-1398 \\ Ivan Carlos Fernandes Martins² (1) https://orcid.org/0000-0002-4405-2713 \\ Janisete Gomes Silva ${ }^{3}$ (10) https://orcid.org/0000-0002-5570-5484 \\ Walkymário Paulo Lemos ${ }^{4, *}$ (1D https://orcid.org/0000-0002-1608-9551
}
1. Superintendência do Desenvolvimento da Amazônia - Diretoria de Desenvolvimento Sustentável e Inclusão Social - Coordenação-Geral de Inclusão Social e Desenvolvimento Sustentável - Belém (PA), Brazil.
2. Universidade Federal Rural da Amazônia - Campus de Capanema - Capanema (PA), Brazil.
3. Universidade Estadual de Santa Cruz - Departamento de Ciências Biológicas - Programa de Pós-Graduação em Genética e Biologia Molecular - Ilhéus (BA), Brazil.
4. Embrapa Amazônia Oriental - Laboratório de Entomologia - Belém (PA), Brazil.
*Corresponding author: walkymario.lemos@embrapa.br

\begin{abstract}
The state of Pará has oil palm plantings of different ages and distinct genotypes. The understanding of which factors influence the occurrence and abundance of defoliating caterpillars in palm groves is paramount for control strategies based on integrated pest management (IPM). This study quantified the effect of oil palm age independently, and that of oil palm age and genotype, on the occurrence and abundance of defoliating caterpillars. Data were collected from 1994-2014 and consisted of counting the average number of caterpillars/leaf/parcel. For Opsiphanes invirae and Talima sp., leaf 17 was sampled; for Acharia spp., Euclea sp., Euprosterna elaeasa, Natada sp., and Automeris liberia, leaf 25 was sampled. For Oiketicus kirbyi, Antaeotricha sp., and Brassolis sophorae no specific leaf was considered. Palm trees were classified into three groups: young palm trees (0-8 years after planting), adult palm trees (9-19 years after planting), and old palm trees (over 20 years after planting). Talima sp. showed the highest population peak followed by O. invirae, Acharia spp., Elaeis elaeasa and Euclea sp. This study concludes that genotype has an impact on the infestation by defoliating caterpillars. Also, oil palms at reproductive age are more prone to higher infestation levels than young trees. While population levels of defoliating caterpillars are low in general, outbreaks are frequent. Importantly, intraspecific genotypes are more vulnerable than interspecific genotypes to infestations by defoliating caterpillars. This study contributes to the bioecological knowledge on defoliating caterpillars on oil palm and therefore provides important information to strengthen integrated pest management practices.
\end{abstract}

Keywords: Elaeis guineensis; Opsiphanes invirae (Hübner, 1808); Pará; oil palm pests, Talima sp. Walker 1855.

\section{INTRODUCTION}

The oil palm, also known as dendê, (Elaeis guineensis Jacq.; Arecaceae) was first introduced in Brazil in the state of Bahia by African slaves in the XVI century (MÜLLER; ANDRADE, 2010). Brazil is an important oil palm producer with up to $6 \mathrm{t} / \mathrm{ha} /$ year (BROKAMP et al., 2011). However, this production is directly affected by factors such as oil palm genotype and climate (BASTOS et al., 2008). The state of Pará is the largest producer of oil palm fruit bunches and has the largest harvestable area in Brazil (IBGE, 2021). However, oil palm production is far below the potential for developing this crop in the Amazon region.

The genus Elaeis has three species, and both E. guineensis, the oil palm, and Elaeis oleifera (Kunth) (Arecaceae), known as caiaué, are of agronomic and economic importance. Elaeis guineensis can be classified by the thickness of the endocarp (shell) into three botanical variety: Dura (D), Psifera (P), and Tenera (T). The hybrid Tenera is derived from crosses between Dura females and Psifera males $(\mathrm{D} \times \mathrm{P})$. Tenera is considered an improved variety and is the most

Received: Sep 18, 2020. Accepted: Oct 31. 2021

Associate Editor: Silvia Galleti

Peer Review History: Double-blind Peer Review. 
used in commercial palm groves (CUNHA et al., 2010). Elaeis oleifera is used in genetic breeding programs in crosses with E. guineensis (E. oleifera $\times$ E. guineensis), which result in fertile hybrids (CUNHA et al., 2010; GOMES JÚNIOR et al., 2014). Several intra- and interspecific genotypes have been used in the commercial palm groves in the state of Pará, especially the intraspecific offspring from E. guineensis, as Deli $\times$ Lamé, Deli $\times$ Ghana, Deli $\times$ Nigéria, Deli $\times$ Ekona, and interspecific offspring from Compacta $\times$ Nigéria, Compacta $\times$ Ghana, and Compacta $\times$ Ekona (ALVES, 2011).

In the state of Pará, there are five producing regions (Belém, Bonito, Moju, Tomé-Açu, and Tailândia) consisting of three planting cycles of oil palms representing different tree ages and distinct genotypes. The first region had 25 to 30 -year-old groves of E. guineensis, which are in the process of being replaced; the second region has 15 to 20 -year-old groves of E. guineensis and hybrids (E. oleifera $\times$ E. guineensis); and the last region has groves less than 10-year-old consisting of varieties of E. guineensis and hybrids with different percentages of E. oleifera parentage (ALVES et al., 2013). Pará ranks first in the production of oil palm (SEDAP-PA, 2020). However, production is affected by the presence of pests. Among these, the defoliating caterpillars are one of the most devastating. Thus, the understanding of what factors influence the occurrence and abundance of defoliating caterpillars in the palm groves is paramount for the effective adoption of control strategies that are better connected to the reality of the Amazon region, especially those based on Integrated Pest Management (IPM) strategies.

This research aimed to contribute to the IPM know-how as it is applied to oil palm groves and the reduction of populations of defoliating caterpillars in the state of Pará. Thus, this study quantified the effect of oil palm age, as well as that of oil palm age associated with various genotypes, on the occurrence and abundance of defoliating caterpillars. The following questions were investigated: (i) Does the occurrence of defoliating caterpillars in oil palm groves vary according to their age? (ii) How does palm grove age affect the occurrence of defoliating caterpillars on different genotypes?

\section{MATERIAL AND METHODS}

This study was carried out on the Agropalma S/A farm in the microregion of Tomé-Açu, state of Pará, Brazil from 1994 to 2014. The following species of defoliating caterpillars were studied: Opsiphanes invirae (Hübner, 1808) (Lepidoptera: Nymphalidae); Brassolis sophorae (Linnaeus, 1758) (Lepidoptera: Nymphalidae); Oiketicus kirbyi Guilding (Lands.-Guilding, 1827) (Lepidoptera: Psychidae); Automeris liberia (Walker, 1855) (Lepidoptera: Saturniidae); Antaeotricha sp. Zeller 1854 (Lepidoptera: Elachistidae); Euclea sp. Hübner, 1819 (Lepidoptera: Limacodidae); Euprosterna elaeasa Dyar (1906) (Lepidoptera: Limacodidae); Natada sp. Walker 1855 (Lepidoptera: Limacodidae); Acharia spp. Hübner, (1819) (Lepidoptera: Limacodidae); and Talima sp. Walker 1855 (Lepidoptera: Limacodidae).

Two sampling strategies were tested along the course of the study. The first round of sampling focused on the grove edges, as a previous study indicated that these insects invade groves from the edges (GENTY et al., 1978). However, after the establishment of these pests in the groves, the sampling strategy was changed to double sampling along the grove edges consisting of three or more tree rows, as well as in the center of the grove. A pilot sampling of the number of caterpillars per leaf was previously carried out in order to test the efficacy of this strategy. The numbers were higher in the double sampling, which thus was the strategy of choice implemented for this study.

Tree row choice was predetermined, and rows 10, 60 and 110 were chosen for sampling. Due to differences in parcel size, sampling was standardized with the variation between the number of rows sampled according to parcel size. In larger parcels (usually with 128 rows and 120 ha), sampling was done in the edge and central rows in which leaves 17 or 25 were sampled. In smaller parcels (25-30 ha), sampling was done at every 10 rows initiating in the 4th or 5th row with leaves either 17 or 25 sampled from 10 plants per row. Despite the changes in the number of rows and plants sampled in each parcel, the average number of caterpillars/leaf/parcel remained unaltered. When resampling was necessary, either in the same or in the next insect life cycle, the same row was used. However, leaves were taken from another tree adjacent to the one previously sampled.

Monitoring of the defoliating caterpillars was based on inventory maps of the oil palm groves with parcels, rows, and sampled plants identified and organized with information included from previous observations by the farm staff. Adults of $O$. invirae were collected using attractive traps, similar to that described by LORYA et al. (2002), and then quantified. Caterpillars of the remaining species were observed and quantified daily by the farm staff. After the presence of the caterpillars in parcels was reported, and with the aid of maps and the plants previously identified, specific leaves were cut for sampling of the defoliating caterpillars. For O. invirae and Talima sp., leaf 17 was sampled, and for Acharia spp., Euclea sp., E. elaeasa, and A. liberia leaf 25 was sampled. For O. kirbyi, B. sophorae, and Antaeotricha sp., no leaf was predetermined for sampling and thus any palm leaf with bags and nests (GENTY et al., 1978) was considered for sampling. After being cut, leaves were 
carefully examined, and the number of caterpillars on the abaxial side was registered leaflet by leaflet. In the absence of the leaf to be sampled, either the preceding or posterior leaf in the same spiral was cut, and this same procedure was adopted in case the plant was cut down, struck by lightning or diseased.

The data were grouped into three categories: (i) young palm trees (0-8 years after planting), (ii) adult palm trees (9-19 years after planting), and (iii) old palm trees (over 20 years after planting). A total of 12,463 parcels with young palm trees, 34,703 parcels with adult palm trees and 12,011 parcels with old palm trees were analyzed. The data were examined using the Kruskal-Wallis $(\mathrm{H})$ analysis of variance followed by post-hoc Mann-Whitney with Bonferroni adjustment, and the significance level was divided by the total number of groups tested with the significance of $\alpha=0.05 / 3=0.0167$ for each test. Relevant assumptions were evaluated according to the post hoc procedures described by FIELD (2009). Statistical analysis was done on SPSS v.17 (SPSS Inc, Chicago, IL, USA).

\section{RESULTS AND DISCUSSION}

The highest population peaks were observed for Talima sp., followed by O. invirae, Acharia spp., E. elaeasa, and Euclea sp. (Fig. 1a). It is quite possible that such peaks are the result of declines of populations of natural enemies, which otherwise help to maintain the population balance of defoliating caterpillars in the oil palm groves in the state of Pará (TINÔCO, 2008). This may also be due to the fact that the local climatic conditions do not have a negative influence on the populations of these insects (OLIVEIRA, 2016). Outbreaks of Talima sp. had been previously reported (GENTY; LÓPEZ, 2013), which reveals the strategic importance of taking appropriate control measures immediately after the first specimens are detected in the oil palm groves in order to avoid future outbreaks.

The occurrence of lepidopterans varied according to oil palm grove age and genotype, which confirmed one of the hypotheses tested (Fig. 1b-c). Regardless of the genotypes, the most severe outbreaks occurred in groves with adult oil palms (Fig. 1b). When genotypes were also considered, the largest numbers of caterpillars were observed in the genotypes Deli $\times$ Lamé and Deli $\times$ Lamé + Deli $\times$ Yangambi (Fig. 1c). It was verified that palm age affected the average number of caterpillars $(\mathrm{H}[2]=3,954, \mathrm{p}<0.05]$, since there was a decline in the average number of caterpillars when comparing their incidence in young trees to old trees $\left(\mathrm{U}=5.6 \times 10^{7}, \mathrm{r}=-0.233\right)$ or adult trees to old trees $\left(\mathrm{U}=1.28 \times 10^{8}, \mathrm{r}=-0.294\right)$. This effect was not observed when comparing young trees to adult trees $\left(\mathrm{U}=1.95 \times 10^{8}, \mathrm{r}=-0.079\right)$, whose average number of caterpillars remained similar.

The results of this study confirmed that oil palm genotype and age also influence the number of defoliating caterpillars in oil palm groves. This latter result, however, is not unexpected since young oil palms usually grow up free of phytosanitary problems in the first years after planting (DÍAZ et al., 2000; PÉREZ, 2010). Furthermore, the transformation of extensive areas into monoculture, local ecological conditions in the groves, agronomic management, and rainfall had been reported as agents influencing the number of defoliating caterpillars in oil palm groves (DÍAZ et al., 2000).

Since Talima sp., O. invirae, Acharia spp., E. elaeasa, and Euclea sp. showed the highest population densities (Fig. 1a), their population fluctuations were plotted versus oil palm grove age (Fig. 2). Overall abundance of these populations was higher at the peak of the reproductive cycle of the oil palms between the 7th and 10th year after planting. Outbreaks of Talima sp. started after the 10th year after planting and declined from the 17 th year on. Population peaks of $O$. invirae were more frequent in the 7th and 8th years after planting, although the incidence of this particular species had been regular in oil palm groves of all ages. Outbreaks of Acharia spp. started in the 8th year after planting and declined from the 15th year on, whereas the highest infestations by Euclea sp. were observed in the 10th year after planting (Fig. 2).

The results of the present study showed the relationship between the occurrence of the defoliating caterpillars and the reproductive phenology of the oil palms (Fig. 2). According to BARCELOS et al. (1995), oil palms start fruiting after the 4th year after planting and gradually increase production up to the 8th year when they reach a peak production. The production remains at peak levels until the 16th year and then declines. This study revealed that not all species of defoliating caterpillars were frequent in the oil palm groves at peak production. This was demonstrated during outbreaks of $E$. elaeasa that began in the 17th year after planting (Fig. 2). Perennial crops such as oil palm tend to stabilize over time, reducing pest outbreaks. Stabilized perennial crops require less maintenance and present favorable conditions for the appearance of natural enemies and consequently a decrease in pests (TOOKER et al., 2020; WALLNER, 1987). However, this stabilization depends on the crop type and degree of human intervention, thus suggesting that older crops have less anthropogenic influence. It is quite possible that crop stability might have been determinant for a lower incidence of defoliating caterpillars in the oil palms from the 16th year. However, the physiological state of trees and their reproductive age might have also determined the occurrence of defoliating caterpillars in the palm groves studied. 
(a)
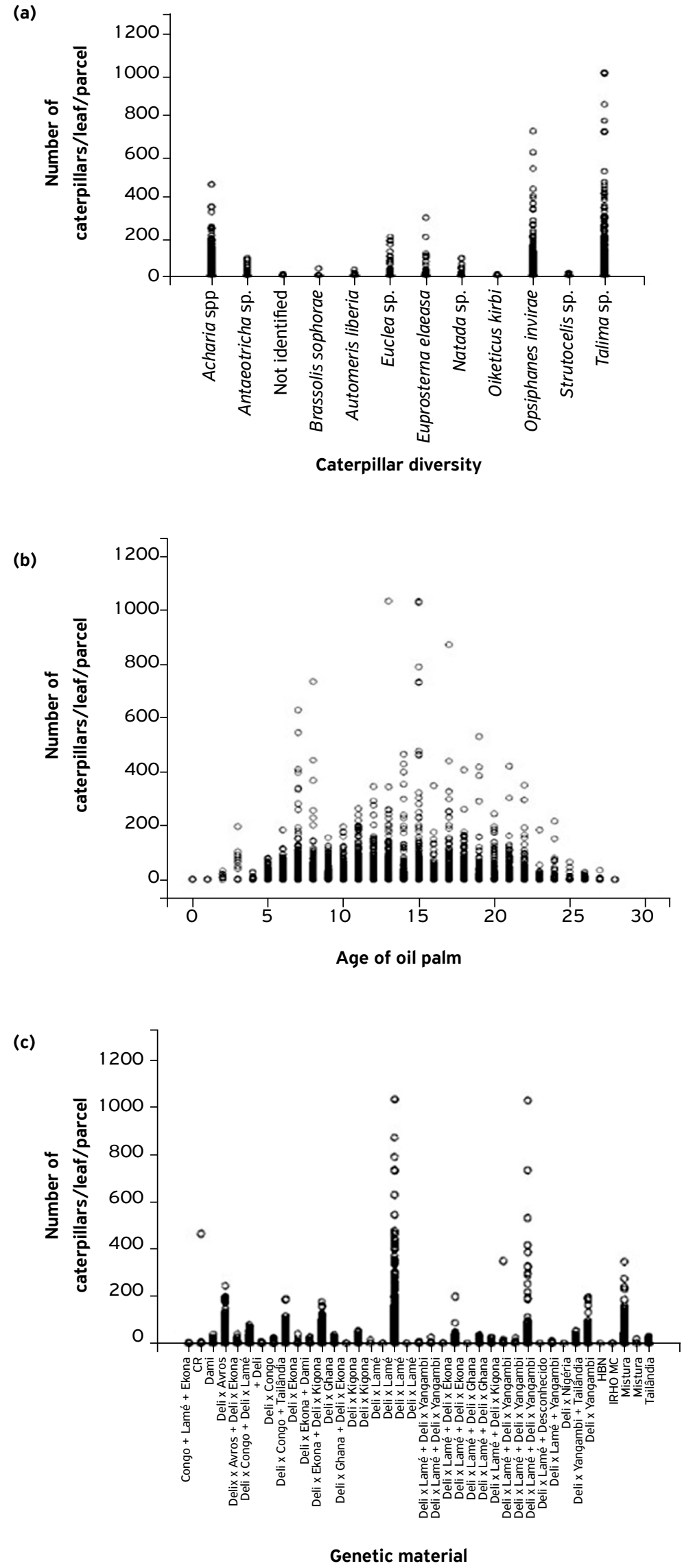

Figure 1. Number of caterpillars/leaf/parcel in oil palm (Elaeis guineensis).

Source: Elaborated by the authors using data form Agropalma S/A Company form a historical series (1994-2014). 

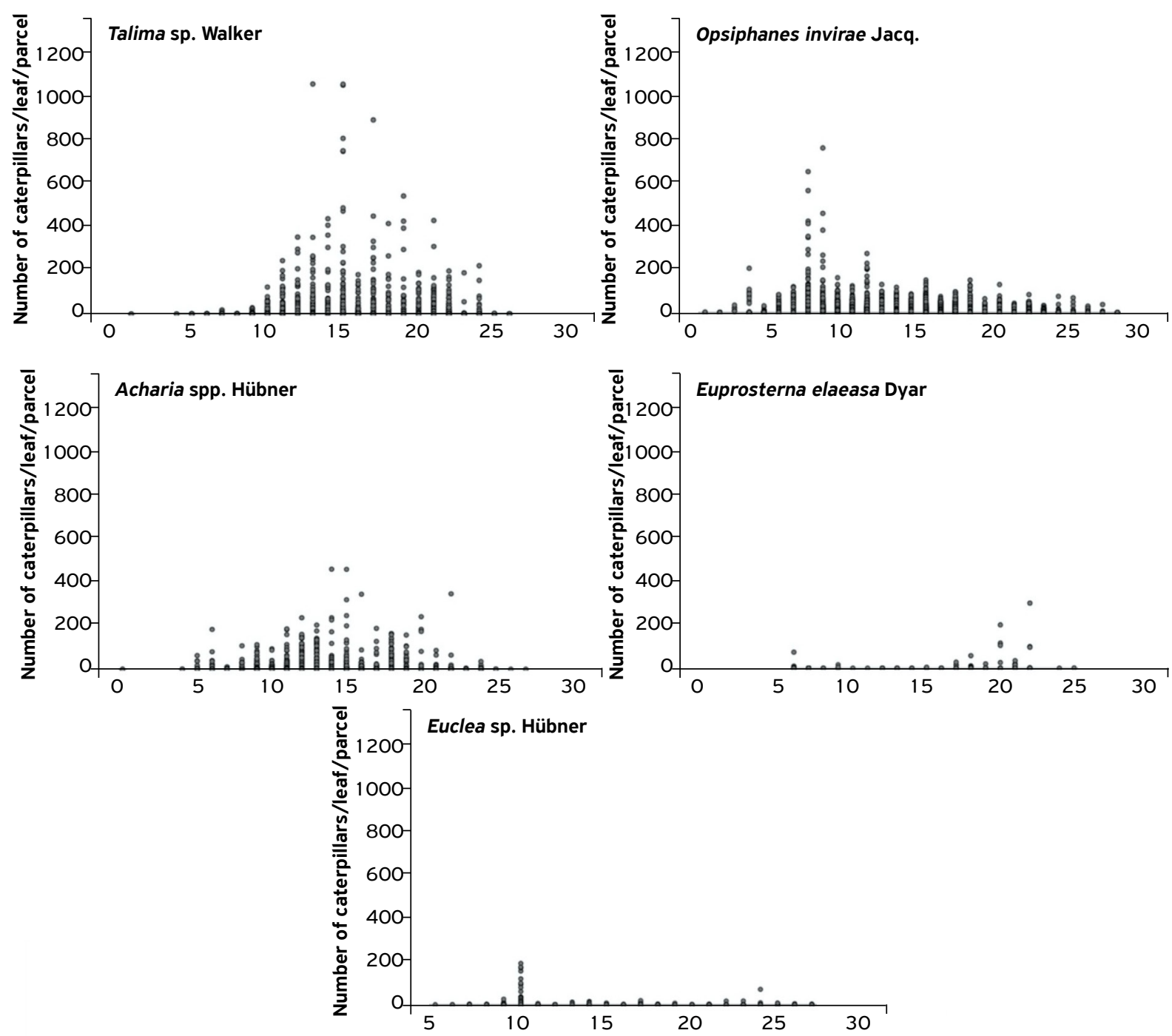

Figure 2. Number of caterpillars/leaf/parcel according to age of oil palm.

Source: Elaborated by the authors using data form Agropalma S/A company from a historical series (1994-2014).

The occurrence of defoliating caterpillars is positively associated with the reproductive phenology of the oil palm, and their decline is coupled with tree ageing. The occurrence of pests may vary in the different phenological stages of the plants and this verification contributes to their management (KULKARNI et al., 2019). Given that set of factors, it is suggested, however, that population monitoring should start in young groves from the 4 th year. The aim of this effort should be the early detection and treatment of incipient caterpillar population increases, and, thus, the prevention of future outbreaks occurring at the strategic periods representing peak oil palm production and harvest. The results of this study differ from those of MEXZÓN; CHINCHILLA (2003), who proposed that a lower abundance of pests was observed in younger groves due to a higher incidence of sunlight, less developed leaves, and high richness of natural enemies. Whereas older groves have a microclimate that favors the development and multiplication of insect pests and the decline of beneficial species.

This study confirmed that the abundance of defoliating caterpillars in oil palm groves depends on the interaction of oil palm genotype and age. Moreover, this relationship was observed in the most frequently grown genotypes. Thus, it was verified that defoliating caterpillars were more abundant in young Deli $\times$ Avros and Deli $\times$ Ekona oil palms. In contrast, in Deli $\times$ Lamé and Deli $\times$ Ghana, the incidence of these insects was higher in mature trees (Table 1).

Regarding the effect of genotypes on the occurrence of defoliating caterpillars, it was observed that among interspecific genotypes the occurrence of these insects was lower regardless of grove age. The high number of caterpillars observed in trees of the genotype Deli $\times$ Lamé (Fig. 1c) is worrisome, as this is the most used genotype in the state of Pará and worldwide due to its high yield (ALVES et al., 2013). The results of the present study are relevant for the adoption of control strategies in oil palm groves that are better grounded to the reality of the Brazilian Amazon. The chemical composition and physical characteristics (e.g., hardness and wax layer) of genotypes may have influenced the number of caterpillars among several genotypes studied, 
but these variables were not the focus of this study. However, the evaluation of such variables is very important to reveal the relationship between defoliating caterpillars and oil palm. For instance, a recent laboratory study verified that the genotype Deli $\times$ Lamé was less consumed by 12 -day-old caterpillars of $O$. invirae, whereas Compacta $\times$ Ghana was more palatable for both recently emerged and 12-day-old caterpillars (MAIA et al., 2018). This same study revealed that the genotype Compacta $\times$ Nigéria showed nonpreference type of resistance to recently emerged $O$. invirae caterpillars, whereas Compacta $\times$ Ekona and Compacta $\times$ Ghana were susceptible. Further studies on the defoliating caterpillars that feed on oil palms in the state of Pará should also examine the physical-chemical characteristics of oil palms.

Table 1. The average number of caterpillars/leaf/parcel per genotype and oil palm grove age in the microregion of Tomé-Açu, state of Pará.

\begin{tabular}{lcc}
\hline Genotypes & Grove age & Number of caterpillars/leaf \\
\hline \multirow{3}{*}{ Deli $\times$ Avros } & Young & 773 \\
& Adult & 6,973 \\
\cline { 2 - 3 } Deli $\times$ Ekona & Old & 1,188 \\
& Young & 3,345 \\
\hline \multirow{3}{*}{ Deli $\times$ Ghana } & Adult & 2,873 \\
\cline { 2 - 3 } & Old & 13 \\
\hline \multirow{3}{*}{ Deli $\times$ Lamé } & Young & 2,037 \\
\cline { 2 - 3 } & Adult & 1,550 \\
\hline \multirow{2}{*}{ Mixed } & - & 4,271 \\
\cline { 2 - 3 } & Young & 15,968 \\
\cline { 2 - 3 } & Adult & 7,069 \\
\hline
\end{tabular}

- noncultivated, which means it is not present in old groves.

Source: Elaborated by the authors using data form Agropalma S/A Company from a historical series (1994-2014).

\section{CONCLUSION}

Oil palm age and genotype have an impact on the abundance of defoliating caterpillars in oil palm groves. In this regard, oil palms at the reproductive age in the state of Pará are more prone to higher infestation levels of defoliating caterpillars, except for E. elaeasa, which prefers oil palm groves with declining production levels. In addition, intraspecific genotypes are more infested by defoliating caterpillars in the state of Pará, and the Deli $\times$ Lamé was the most infested genotype. Ultimately, population levels of defoliating caterpillars are low in general; however, outbreaks of Talima sp. are frequent in older oil palm groves.

\section{AUTHORS' CONTRIBUTIONS}

Writing - original: Oliveira, T.A; Lemos, W.P. Writing - review: Martins, I.C.F; Silva, J.G. Data analysis: Oliveira, T.A. Methodology: Oliveira, T.A.; Lemos, W.P.; Martins, I.C.F.

\section{AVAILABILITY OF DATA AND MATERIAL}

The datasets generated and/or analyzed during the current study are available from the corresponding author on reasonable request.

\section{FUNDING}

Conselho Nacional de Desenvolvimento Científico e Tecnológico

https://doi.org/10.13039/501100003593

Grants no.: 140674/2012-8, 309016/2018-5 and $311298 / 2015-0$

\section{CONFLICTS OF INTEREST}

All authors declare that they have no conflict of interest.

\section{ETHICAL APPROVAL}

Not applicable.

\section{ACKNOWLEDGEMENTS}

To Agropalma S/A for allowing us to use their data from the historical series of monitoring and for the support during the study, to Carter Robert Miller for revising a previous version of the manuscript and Dayan Rios for helping with data analyses. 


\section{REFERENCES}

ALVES, S.A.O. Sustentabilidade da agroindústria de palma no estado do Pará. 2011. Dissertation (Doctoral in Sciences) - Escola Superior de Agricultura "Luiz de Queiroz", Universidade de São Paulo, Piracicaba, 2011. Available from: https://www.teses.usp.br/teses/ disponiveis/11/11150/tde-24112011-162833/publico/Sergio_Augusto_Oliveira_Alves_versao_revisada.pdf. Access on: 15 May 2019.

ALVES, S.A.O.; AMARAL, W.A.N.; HORBACH, M.A.; ANTIQUEIRA, L.M.O.R.; BRAGA, L.P.P.; DIAS, I.F.S. A dendeicultura no estado do Pará: Cenário atual, entraves e perspectivas. Bioenergia em Revista: Diálogos, Piracicaba, v.3, n.2, p.18-28, 2013. Available from: http:// www.fatecpiracicaba.edu.br/revista/index.php/bioenergiaemrevista/article/view/98. Access on: 7 Mar. 2019.

BARCELOS, E.; CHAILLARD, H.; NUNES, C.D.M.; MACÊDO, J.L.V.; RODRIGUES, M.R.L.; CUNHA, R.N.V.; TAVARES, A.M.; DANTAS, J.C.R.; BORGES, R.S.; SANTOS, W.C. A cultura do dendê. Brasília: Embrapa-SPI, 1995. 68p. Available from: https://www.infoteca.cnptia. embrapa.br/bitstream/doc/100649/1/00013560.pdf. Access on: 15 May 2019.

BASTOS, T.X.; MÜLLER, A.A.; RAMALHO FILHO, A.; PACHÊCO, N.A.; GONÇALVES, A.O.; MONTEIRO, D.C.A. Zoneamento agroclimático e de riscos climáticos para o cultivo do dendezeiro no Estado do Pará (Documentos 319). Belém: Embrapa Amazônia Oriental, 2008. 26p. Available from: https://ainfo.cnptia.embrapa.br/digital/bitstream/item/28306/1/Doc319.pdf. Access on: 28 Feb. 2019.

BROKAMP, G.; VALDERRAMA, N.; MITTELBACH, M.; GRANDEZ, C.A.R.; BARFOD, A.S.; WEIGEND, M. Trade in palm products in North-Western South America. The Botanical Review, New York, v.77, p.571-606, 2011. https://doi.org/10.1007/s12229-011-9087-7

CUNHA, R.N.V.; LOPES, R.; GOMES JÚNIOR, R.A.; RODRIGUES, M.R.L.; TEIXEIRA, P.C.; ROCHA, R.N.C.; LIMA W.A.A. Material genético utilizado para a produção sustentável da cultura da palma de óleo na Amazônia. In: FREITAS, P.L.; TEIXEIRA, W.G. (eds). Zoneamento agroecológico, produção e manejo para a cultura da palma de óleo na Amazônia. Rio de Janeiro: Embrapa Solos, 2010. Parte II, chap.3, p.93-100.

DÍAZ, A.; GONZÁLEZ, C.; VILLALBA, V.; RODRÍGUEZ, G. Evaluación de insectos desfoliadores y de sus enemigos naturales em plantaciones de palma de aceite (Elaeis guineensis Jacq.) del oriente de Venezuela. Revista PALMAS, Bogotá, v.21, n.Especial, p.195-200, 2000. Available from: https://publicaciones.fedepalma.org/index.php/palmas/article/view/784. Access on: 14 May 2019.

FIELD, A. Descobrindo a estatística usando SPSS. Porto Alegre: Artmed, 2009. 688p.

GENTY, P.; DESMIER DE CHENON, R.; MORIN, J.P.; KORYTKOWSKI, C.A. Las plagas de la palma aceitera en América Latina. Oléagineux, France, v.33, p.324-594, 1978.

GENTY, P.; LÓPEZ, M.R.U. Relatos sobre el híbrido interespecífico de palma de aceite OxG - Coari × La Mé: Esperanza para el trópico. Bogotá: Fedepalma, 2013.567p.

GOMES JÚNIOR, R.A.; GURGEL, F.L.; PEIXOTO, L.A.; BHERING, L.L.; CUNHA, R.N.V.; LOPES, R.; PINA, A.J.A.; VEIGA, A.S. Evaluation of interspecific hybrids of palm oil reveals great genetic variability and potential selection gain. Industrial Crops and Products, Fargo, v.52, p.512-518, 2014. https://doi.org/10.1016/j.indcrop.2013.10.036

IBGE - Instituto Brasileiro de Geografia e Estatística. Produção Agrícola - Lavoura Permanente. Rio de Janeiro: IBGE, 2021. Available from: https://cidades.ibge.gov.br/brasil/pa/pesquisa/15/11863?tipo=ranking\&indicador=11938\&ano=2020. Access on: 10 Nov. 2021 .

KULKARNI, S.; CHAKRAVARTHY, A.K.; KUMAR, N. Effects of plant phenological factors on insect pest infestation. In: CHAKRAVARTHY A.K.; SELVANARAYANAN V. (eds). Experimental techniques in host-plant resistance. Singapore: Springer, 2019. p.233-237. https://doi. org/10.1007/978-981-13-2652-3_23

LORYA, R.; CHINCHILLA, C.M.; DOMÍNGUEZ, J.; MEXZÓN R.R. Una trampa efectiva para capturar adultos de Opsiphanes cassina Felder (Lepidóptera: Brassolidae) y observaciones sobre el comportamiento de la plaga en palma de aceite. Revista PALMAS, Bogotá, v.23, n.1, p.29-37, 2002. Available from: https://publicaciones.fedepalma.org/index.php/palmas/article/view/907. Access on: 18 May 2019.

MAIA, P.S.P.; BOIÇA JUNIOR, A.L.; TINÔCO R.S.; FARIAS, P.R.S.; RODRIGUES, N.E.L.; CRISTO, S.T.B. Preferência alimentar de Opsiphanes invirae em cultivares de palma de óleo. Revista de Ciências Agrárias - Amazon Journal of Agricultural and Environmental Sciences, Belém, v.61, p.1-7, 2018. https://doi.org/10.22491/rca.2018.2390 
MEXZÓN, R.G.; CHINCHILLA, C.M. Especies vegetales atrayentes de la entornofauna benéfica en plantaciones de palma de aceite (Elaeis guineensis Jacq.) en Costa Rica. Revista PALMAS, Bogotá, v.24, n.1, p.33-57, 2003. Available from: https://publicaciones.fedepalma.org/ index.php/palmas/article/view/951. Access on: 13 May 2019.

MÜLLER, A.G.; ANDRADE, E.B. Aspectos gerais sobre a fenologia da cultura da palma de óleo. In: FREITAS, P.L.; TEIXEIRA W.G. (eds.). Zoneamento agroecológico, produção e manejo para a cultura da palma de óleo na Amazônia. Rio de Janeiro: Embrapa Solos, 2010. Part II, chap.2, p.83-92.

OLIVEIRA, T.A. Avanços no conhecimento sobre lepidópteros desfolhadores da palma de óleo (Elaeis guineensis Jacq. Arecaceae) na microrregião de Tomé-Açu, Pará. 2016. Dissertation (Doctoral in Agrarian Sciences) - Universidade Federal Rural da Amazônia, Belém, 2016.

PÉREZ, C.A.D. Correlación de larvas de Opsiphanes cassina, em hoja 9 y 17 de palma de aceite. 2010. Specialization (Specialist in Industrial Perennial Crops) - Facultad de Agronomia, Universidad Nacional de Colômbia, Bogotá, 2010. Available from: https://repositorio.unal. edu.co/bitstream/handle/unal/70452/carlosalexanderdazaperez.2010.pdf. Access on: 15 May 2019.

TINÔCO, R.S. Inimigos naturais e Lepidópteros desfolhadores associados a Elaeis guineensis Jacq., na Agropalma, Amazônia brasileira. 2008. Thesis (Master in Science) - Universidade Federal de Viçosa, Viçosa, 2008. Available from: https://www.locus.ufv.br/bitstream/123456789/3920/1/ texto\%20completo.pdf. Access on: 17 Mar. 2019.

TOOKER, J.F.; O’NEAL, M.E.; RODRIGUEZ-SAONA, C. Balancing disturbance and conservation in agroecosystems to improve biological control. Annual Review Entomology, Palo Alto, v.65, p.81-100, 2020. https://doi.org/10.1146/annurev-ento-011019-025143

WALLNER, W.E. Factors affecting insect population dynamics: Differences between Outbreak and Non-Outbreak species. Annual Review Entomology, Palo Alto, v.32, p.317-340, 1987. https://doi.org/10.1146/annurev.en.32.010187.001533 